\title{
Social Studies Learning Model for Early Childhood
}

\author{
$1^{\text {st }}$ Huriah Rachmah ${ }^{*}$ \\ Faculty of Tarbiyah and Teacher Training, \\ Universitas Islam Bandung, Indonesia \\ huriahrachmah@gmail.com \\ $2^{\text {nd }}$ Erhamwilda \\ Faculty of Tarbiyah and Teacher Training, \\ Universitas Islam Bandung, Indonesia
}

\author{
$3^{\text {rd }}$ Adang M. Tsaury \\ Faculty of Tarbiyah and Teacher Training, \\ Universitas Islam Bandung, Indonesia
}

\begin{abstract}
Early childhood education is organized by age group and type of service from the child's birth to the age of 6 years. At the age of 0-6 years the brain develops very quickly to $80 \%$ of the ability of the brain. From an early age, children can be given habituation and role models so they can build character early on, including social character. Social character can be formed by early childhood education teachers by knowing the basics of social studies science which are then integrated in the form of play activities. The social studies learning model for early childhood involves not only teachers but also education personnel, parents and the community. This paper was written with the aim to find out the social study learning
\end{abstract}

\section{INTRODUCTION}

Early childhood education is a coaching effort aimed at children from birth until the age of six. Early childhood are given educational stimuli that can help physical and spiritual growth and development so that children have readiness to enter further education. Services can be in the form of day care parks, playgroups, kindergartens/raudhatul athfal/bustanul athfal [1]. In the 2013 early childhood education curriculum, development programs are focused on religious and moral, physical-motor, cognitive, language, artistic and social emotional values.

Social emotional development in early childhood can not be separated. The discussion design conducted on early childhood teacher education students so that when they become teachers, they are able to apply in the classroom. The research method used is participatory action research involving students to produce a social change. Students involved are divided into groups, and given the same format for one particular action so that it becomes a learning activity. After going through a discussion process to receive input and suggestions from colleagues and lecturers, a class simulation was conducted. The simulation results are applied in schools that have been selected by students and documented and uploaded to YouTube.

$$
\text { Keywords-Social Studies, Early }
$$

of children's emotions will depend on their social abilities and vice versa because the positive emotional social development will help children interact with each other [2] [3] [4]. In QS Ali Imran verse 159, social attitudes that should be possessed by everyone are gentle, forgiving, and deliberating.So that, everyone has a sense of empathy, mutual respect, respect for others, tolerance, caring, tolerant and have solidarity [5]. Children's education in Islam refers to Ibn Sina must be directed to the physical, intellectual and moral development. Character education including social education given to children must be based on the concept of faith so that the child's behavior always adjusts to the faith because the nature of every 
child is faith in God, parents make the child become a Christian or an academic [6].

Children need role models from adults so that their development can be better including from the teacher. For this reason, it is necessary to have courses that are able to equip prospective teachers to detect social, emotional and independence abilities of early childhood [1]. The course is a social study for early childhood that is developed in accordance with the principles of learning in early childhood education, namely learning through play, centering on children, active learning, oriented to the development of character values, life skills and democratic [7].

Core competence in social studies courses for early childhood is to have the ability to provide assistance and work together with parents and early childhood so that they have knowledge and understanding of citizenship, economics, culture and the environment of the community in the past, present and future, so can be part of the environment. The basic competency of students is the ability to plan and develop various activities and games that stimulate children's social skills through simulations on citizenship, economics, culture and environment.So that, they are able to solve problems and make simple decisions. Course description contains planning and implementation and evaluation of early childhood social studies by involving early childhood in the world experienced, providing skills in problem solving, making decisions, working independently and socially responsible through games and simulations, and practice reports [8].

The Semester learning plan refers to the 2013 early childhood education curriculum and the understanding of social studies according to the NCSS. Social studies are studies that integrate social science and humanities to produce competent citizens. Social studies programs in schools are a picture of systematic and coordinative studies of various simplified social science disciplines such as anthropology, archeology, economics, geography, history, law, philosophy, political science, psychology, religion, sociology and which are sourced from humanities, mathematics and IPA [9]. The main goal is to help young people to develop their ability to make decisions and make citizens responsible in the midst of a culturally diverse, democratic and interdependent society. The principles of social study are: meaningful (connecting, developing ideas, good content, interaction, student-centered), integrative (interdisciplinary, cross space and time, connecting affective, cognitive, psychomotor; use of technology, connected with other subjects), value based (ethics, critical thinking, respect, social responsibility), challenging (achieving individual and group goals, setting examples, student-oriented), active learning (teachers and students involved in decision making, independent students, social skills, social thinking).

Standard themes in social studies are cultural and cultural differences; time, sustainability and change; human, place and environment; individual development and identity; individuals, groups and institutions; power, authority and governance; production, distribution and consumption; science, technology and society; global relations; and citizenship. The principle of learning social studies for early childhood is that children can learn anywhere both individually and in groups. Teachers can help early childhood teach values, norms and ethics; cooperating with friends and older people; develop a thematic curriculum; and take advantage of children's interests.

The purpose of this study was to determine the efforts of students in creating effective social study learning processes in study groups or kindergartens. Students focus on helping children in social growth, teaching values, norms and ethics and learning to interact with adults in certain situations such as at home, school, train station, in places of worship, stalls and supermarkets. Students are also introduced to national holidays and the symbol of Indonesia, so that the love of the motherland is planted early on.

\section{METHOD}

The research method used is participatory action research which aims to provide an overview of the learning process of social 
studies by looking at the results of discussions, simulations and practices without conducting analysis and making conclusions in general. The data source as the informant is the $6^{\text {th }}$ semester students of the early childhood teacher education study program which consists of 10 groups. Each group gets a different theme and students who do not appear to act as audiences.

The object of the study consisted of several components, namely discussion and simulation activities in the classroom in Room 11 of the Faculty of Tarbiyah and Teacher Training, Bandung Islamic University and practices in play groups or kindergartens that were reported in video form. The main institution in this study is the researcher, so that he can directly relate to respondents. A data collection technique in research was observation by observing students. Observations made were structured observations by preparing simple observation instruments and non-participant observation when researchers observe videos that have been uploaded on YouTube.

Unstructured interviews were conducted by researchers with each group. Interviews were conducted during the discussion process with duration of 30 minutes and for each week two interviews were conducted for two groups. The documentation observed was a video of the learning process in the playgroup or kindergarten of each group. The interrelation of research questions, data sources and data collection techniques can be seen in the following table:

Table 1. The Interrelation of Research Questions, Data Sources and Collection

\begin{tabular}{|c|c|c|c|}
\hline Question & Data Source & $\begin{array}{l}\text { Data Collection } \\
\text { Technique }\end{array}$ & Required Data Signs \\
\hline \multirow[t]{4}{*}{$\begin{array}{l}\text { How are } \\
\text { students' } \\
\text { efforts in } \\
\text { creating an } \\
\text { effective } \\
\text { social study } \\
\text { learning } \\
\text { process? }\end{array}$} & $\begin{array}{l}\text { Presenter } \\
\text { Group }\end{array}$ & Interview & $\begin{array}{l}\text { Interview Theme: } \\
\text { 1. The process of preparing learning activities } \\
\text { 2. Determination of the purpose of activities, tools } \\
\text { and materials, learning concepts, prayer and } \\
\text { song selection, identification of rules, activities } \\
\text { in the classroom, and parental involvement } \\
\text { 3. Assessment and determination of } \\
\text { reward/punisment }\end{array}$ \\
\hline & Audience & Interview & $\begin{array}{l}\text { Audience response to the preparation of learning } \\
\text { activities for each group. }\end{array}$ \\
\hline & $\begin{array}{l}\text { Event: } \\
\text { Teaching } \\
\text { and } \\
\text { Learning } \\
\text { Activities }\end{array}$ & Observation & $\begin{array}{l}\text { 1. } \text { Open learning activities } \\
\text { 2. Core learning activities } \\
\text { 3. }\end{array}$ \\
\hline & $\begin{array}{l}\text { Document: } \\
\text { Learning } \\
\text { Activities }\end{array}$ & Documentation & $\begin{array}{l}\text { 1. Learning activities are developed according to } \\
\text { the objectives in the syllabus } \\
\text { 2. Determination of the purpose of activities, tools } \\
\text { and materials, learning concepts, prayer and } \\
\text { song selection, identification of rules, activities } \\
\text { in the classroom, and parental involvement. } \\
\text { 3. Video of activities at school }\end{array}$ \\
\hline
\end{tabular}

Data collection and analysis is carried out continuously since the discussion and simulation process is carried out by each group by doing synthesis and analyzed with three 
steps namely data reduction, exposure to empirical material and conclusions and verification. Checking the validity of the results of the discussion and simulation is done by triangulating data. Data triangulation compares the exposure of each group, audience responses and the opinions of other lecturers who participated in the research activities.

\section{RESULTS AND DISCUSSION}

At the first meeting, lecturers supporting the course gave an explanation of the syllabus of social studies courses for early childhood, learning objectives and group division. Students are divided into 10 groups and each given a different activity, namely:

Table 2. Group Activity Theme

\begin{tabular}{cl}
\hline \multicolumn{1}{c}{ Group } & \multicolumn{1}{c}{ Activity } \\
\hline 1 & Learn to obey the rules at home and at school \\
\hline 2 & Play the role of an adult at home and at school \\
\hline 3 & Differentiate yourself from others \\
\hline 4 & Learn to adapt, understand yesterday and present concepts and dailyroutines \\
\hline 5 & Learn to distinguish healthy food, good clothing and a decent place to live \\
\hline 6 & Learning responsibly at home, school, library, hospital and eating places \\
\hline 7 & Learn to do activities at the mosque \\
\hline 9 & Learn to move and behave in public transportation \\
\hline 10 & Learn to know about national holidays and Indonesia's national symbols \\
\hline
\end{tabular}

Each group was asked to identify the target age, location of activities, application in class, tools and materials, prayers taught, and songs memorized by children. In addition, the informant also explained how to give gifts and punishment to children who did not participate in the activities properly. In the activity sheet each group must provide an explanation of how parents are involved in each activity. The involvement of parents is important, because parents are the first and foremost educators. Family environment is the first environment known to children and children always imitate all the behavior of their parents so that parents become one of the parties responsible for the growth and development of children and must continue to learn so that children can become individuals who have good behavior [11] [12].

Purpose of Activities

Each group was asked to explain the purpose of their activities by stating the target age, location of the activity, the methods used in the class and the class setting. A total of eight groups said their target age was 5-6 years. This is possible because in the age range of 5-6 years, gross motor development is rapidly growing and can be seen as an element of maturity and remote control that requires great muscle skills and physical strength and balance, so that the movements that arise are produced from the coordination of the body, muscles and nerves [12] [13]. After the age of 5 years, fine motor development occurs with better coordination using smaller muscles so that it can be used to write, catch balls and use tools [14].

The use of the role playing method which involves the teacher and child is chosen by the whole group. The reason for choosing the role playing method is that each group can set up at the time of the simulation exactly the same as at school during practice. The results of research on role playing shows that the method of role playing can provide tangible experiences in 
children, because children imitate the things done by adults in everyday life [15]. In addition, role playing can improve the ability to socialize early childhood [16] [17].

Tools and Materials

The tools and materials prepared by each group depends on their respective activities. For example, group 8 writes tools and materials in the form of train station signposts, toilet writing, writing to queue, waiting place writing, no smoking symbol, identity card, name tag according to role, mini market writing, counter window, departure schedule board, money toys, train tickets, food and drinks, medicines and jackets. The tools and materials are prepared for learning to behave in public transportation. The term tools and materials in early childhood education is an educational game tool which is a play tool that is able to stimulate all five senses and intelligence of children [18]. Educational game tools can be made by teachers provided they meet the educational, technical and economic requirements so that the teacher will be more creative and be able to make educational game tools in accordance with early childhood development [19].

\section{Prayers and Songs}

Every time playing in early childhood education there are always prayers and songs. In learning activities to get to know healthy food and clothing (group 5) good children are taught to recite prayers before eating, prayers after eating and pray in clothes, pray to take off clothes and pray in mirrors. In the activities to be responsible in every place (group 6) that is often visited by children, children are taught to say and answer greetings, prayers before learning and prayers kifaratul mosque. Teaching prayers in daily life serves to increase faith and piety, the development of religious values, especially Islam [20]. Establishing religious values is making the foundation of faith, personality and character praiseworthy and accustom routine worship so that it can be applied in everyday life in everything that is done [21].

In addition to prayer, children's songs that can provide motivation and contain learning elements are also taught to young children. As in adult role-playing activities (group 2), children are taught the song Ibu Icreated by S.M. Mochtar, Goes to Study by Ibu Sud and My Dear Teacher by Melly Goeslaw. In daily routine learning activities and concepts yesterday / now, children are taught the song Names of the Day and Wake Up. Not all songs are taught not only songs that are already wellknown, but teachers can create lyrics and sing with the tune of songs that are familiar to children. The song is a sound that plays regularly and has a tone, rhythm, melody and harmony that is pleasing to the listener. The results of the study stated that the process of song recognition to children can be through parents and teachers. Children's interest in music is due to the melody of a song that dances for the child as in the song Balonku after the words "burst a green balloon ... Dar" as if to shock the child's emotions. The song also teaches children about color and mathematics [22].

\section{Identify Rules for Each Activity}

The identification of rules in each activity aims to introduce the rules in various places. For example, group 10 on activities in the Bank, doing a series of activities in accordance with the rules in the Bank such as taking a queue number, waiting for a teller to call in the space provided, and coming to the teller with a passbook. Children are taught how to greet others politely and say thank you after getting service. Children need to know various rules with the guidance of parents and teachers in order to practice discipline so that children have limits if they behave wrongly [23].

\section{Praise and Rebuke}

The activities carried out are inseparable from the child's activities. Sometimes children are enthusiastic about participating in every activity, sometimes they don't want to participate at all. Teachers are asked to behave towards what children do either by giving punishment or reward. Praise given can be in the form of words that provide motivation such as "Smart, you are great!" or give stars so that children will feel proud and motivated to continue to do their best. While the punishment 
does not take the form of physical punishment, it is enough to give a reprimand or the stars that have been taken are taken again. Reward is fun for children but should not be considered as a reward because it is no longer worth educating. Prizes are given with the aim of providing motivation in the form of hugs, kisses and sincere words of praise [24]. Punishment can be interpreted as a punishment or sanction and can be allowed to hit with a non-hard punch if the smooth method does not work. This is as stated in the Hadith of the History of Abu Dawud namely: "From Amr Bin Syu'aib from his father from his grandfather said: Raulullah SAW said:" order your children to pray, when they are seven years old, and beat them when they are ten years if they leave prayer and separate them in terms of beds [25]". In Islam, educating children can be followed by following the advice of the Prophet, which is based on compassion and prioritizing punishment. Give an explanation of cause and effect to the child who received a reprimand or punishment, so that the child understands that the warning given so that the child no longer does anything negative.

Based on the results of discussions and interviews, each group conducts a simulation before practice in the classroom. The activity settings are made as closely as possible to the conditions at school, so that students practice at school. All tools and materials are prepared in accordance with the design of activities that have been prepared by each group. After the simulation, each group practices at school. However, due to insufficient time, it was finally agreed that each of the two groups merge into one group that practices at school. The results of the practice at school were made into a video and uploaded to YouTube as proof of performance. The results of the performance of each group can be seen in the following link:

Responsible activities in the library https://www.youtube.com/watch?v=1E8RMUh HD5Q

Role playing activities by learning to fruit shop https://www.youtube.com/watch?v=LpA1YFM enD8

Clothing activities
https://www.youtube.com/watch?v=NPaLN07 $\underline{\mathrm{mfkY}}$

Activities at the train station

https://www.youtube.com/watch?v=yEiSVSBafs

Voting activity

https://www.youtube.com/watch?v=pLcFIKrD1

$\underline{58}$

Activity activities on the Mall

https://www.youtube.com/watch?v=C9OP6Vg

NUxg

In every video that is made, it always starts with praying and explaining the purpose of learning today. After all children understand, the student who acts as the teacher prepares all the tools and materials and teaches the songs that will be performed at the activity on that day. Social interaction and communication are seen between respondents and early childhood. This activity trains the courage of students to directly practice the designs that have been made. After practicing, almost all groups at first felt nervous, but then were happy and able to communicate well to young children.

\section{CONCLUSIONS}

Social studies are studies that integrate social science and humanities to produce competent citizens and help young people to develop their ability to make decisions and make citizens responsible in the midst of culturally diverse, democratic and interdependent societies.Learning social studies for early childhood is important to give, for that early childhood education study program students should be able to design learning programs that are able to help children in establishing communication and interacting with their environment. The goal to be achieved is to help children have good character and have awareness that they are part of Indonesian citizens.

The learning design is made in several activities related to children's daily lives. Learning activities that are prepared are understanding house and school regulations, learning to be an adult, differentiating themselves from others, adapting, understanding the concept of time, daily routines, knowing healthy food, being 
responsible, doing activities in public places and knowing national holidays and national symbols Indonesia.Each activity carried out discussions, simulations and practices so as to provide meaningful experiences to prospective early childhood education teacher students and children who are actively involved in it. The learning method is carried out using the role playing method and is integrated into the themes that exist in the early childhood education curriculum.

\section{ACKNOWLEDGMENTS}

Thank you to the $6^{\text {th }}$ semester students of the early childhood teacher education program, the tarbiyah and teaching faculty, Bandung Islamic University who have worked hard to design activities for early childhood learning and make simulations and practice in kindergarten schools.

\section{REFERENCES}

[1] Permendikbud No. 146. (2014). Kurikulum 2013 Pendidikan Anak Usia Dini. Jakarta: Kementerian Pendidikan dan Kebudayaan.

[2] Suyadi. (2010). Psikomogi Belajar Pendidikan Anak Usia Dini. Yogyakarta: Pedagogis.

[3] Morisson, G. (2012). Dasar-Dasar Pendidikan Anak Usia Dini. Jakarta: Indeks.

[4] Nurjannah. (2017). Mengembangkan Kecerdasan Sosial Emosional Anak Usia Dini Melalui Keteladanan. HISBAH: Jurnal Bimbingan Konseling dan Dakwah Islam, 14(1), pp. 50-61.

[5] Handriyani, P. K. (2014). Pendidikan Sosial yang Terkandung dalam Al-Quran Surat Ali Imran Ayat 159. Jakarta: PAI FTK UIN Syarif Hidayatullah.

[6] Na'in, J., Yasin, M., \& Tohari, 1. (2017). Konsep Pendidikan Anak dalam Perpektif Al-Qur'an (Surat Luqman Ayat 12-19). Edudeena, 1(1), pp. 9-19.

[7] Lampiran IV Permendiknas Nomor 146. (2014). Pedoman Pembelajaran (Kurikulum 2013 Pendidikan Anak Usia Dini). Jakarta: Kementerian Pendidikan dan Kebudayaan.
[8] Rachmah, H., \& Erhamwilda. (2019). Rencana Pembelajaran Semester Mata Kuliah Studi Sosial untuk Anak Usia Dini. Bandung: PG PAUD FTK UNISBA.

[9] National Council for the Social Studies. (2016). A Vision of Powerful Teaching and Learning in the Social Studies. Social Education, 80(2), pp. 180-182.

[10] Fadlillah, M. (2012). Desain Pembelajaran Paud. Jogjakara: Ar-Ruzz Media.

[11] Novrinda, Kurniah, N., \& Yulidesni. (2017). Peran Orang Tua dalam Pendidikan Anak Usia Dini Ditinjau dari Latar Belakang Pendidikan. Jurnal Potensia, 2(1), pp. 39-46.

[12] Sujiono, B. (2010). Metode Pengembangan Keterampilan Motorik Anak Usia Dini. Jakarta: Departemen Pendidikan Nasional.

[13] Yulianingsih. (2015). Pengaruh Senam Irama Terhadap Kemampuan Motorik Anak Usia 5 Tahun. Universitas Muhammadiyah Surakarta. Retrieved Agustus 6, 2019, from ums.ac.id: Retrieved from http://eprints.ums.ac.id/37663/1/NASKA $\mathrm{H}$ \%20PUSBLIKASI.pdf.

[14] Yenny. (2017). Gambaran Perkembangan Motorik Anak Usia 5-6 tahun yang Bermain Games Gadget. Peran Psikologi Perkembangan dalam Penumbuhan Humanitas pada Era Digital (pp.198-214). Semarang: Ikatan Psikologi Perkembangan Indonesia.

[15] Hayati, H. S. (2016). Penerapan Metode Bermain Peran dalam Meningkatkan Kemampuan Berbahasa Anak Usia 5-6 Tahun di TK Kartika 1-4 Pekanbaru. Jurnal Primary, 5(1), pp. 115-124.

[16] Aida, N., \& Rini, R. A. (2015). Penerapan Metode Bermain Peran untuk Meningkatkan KemampuanBersosialisasi Pada Pendidikan Anak Usia Dini. Persona, Jurnal Psikologi Indonesia, 4(1), pp. 87-99.

[17] Aulina, C. N. (2015). Pengaruh Bermain Peran Terhadap Kemampuan Sosial Anak Usia Dini. JournalPedagogia, 4(1), pp. 59-69.

[18] Astini, B. N., Nurhasanah, Rachmayani, I., \& Suarta, I. N. (2017). Identifikasi Pemanfaatan Alat Permainan Edukatif 
dalam Mengembangkan Motorik Halus Anak Usia DIni. Jurnal Pendidikan Anak, 6(1), pp. 31-40.

[19] Anhusadar, L. O. (2016). Kreativitas Pendidik di Lembaga PAUD. Jurnal AlTa'dib, 9(1), pp. 76-93.

[20] Palupi, R. (2018). Penerapan Pengembangan Nilai Agama Anak 5-6 Tahun di TK Bina Anak Islam KrapyakSewon Bantul. Retrieved Agustus 16, 2019, from journal.student.uny.ac.id: Retrieved from http://journal.student.uny.ac.id/ojs/index. php/pgpaud/article/download/11061/106 $\underline{05}$

[21] Mubasyaroh. (2016). Model of Religious Study and Moral Values in TK Putra Harapan Nalumsari Jepara. Ta'dib, 21(2), pp. 191-200.
[22] Wicaksono, R. Y., \& Utomo, U. (2017). Daya Tarik Lagu bagi Anak Usia Dini: Studi Kasus di TK Pertiwi I Singodutan, Wonogiri. Jurnal Seni Musik, 6(2), pp. 9193.

[23] Lukitasari, S. (2017). Deskripsi Kedisiplinan Anak Usia 5-6 Tahun Di KB/TK Pedagogia. JurnalPendidikan Anak Usia Dini, 6(3), pp. 231-240.

[24] Prawira, P. A. (2013). Psikologi Pendidikan dalam Perspektif Baru. Jogjakarta: Ar- Ruzz Media.

[25] Safitri, M. (2017). Konsep Reward dan Punishment dalam Mendidik Anak di Lingkungan Keluarga Menurut Ajaran Rasulullah Saw. Palembang: Fakultas Tarbiyah dan Keguruan UIN Raden Fatah Palembang. 